\title{
Some Physical Properties and Proximate Composition of Ipoli Fruits
}

\section{Burubai $\mathbf{W}^{*}$ and Amber B}

Department of Agricultural and Environmental Engineering, Faculty of Engineering, Niger Delta University, P.M.B. 071, Wilberforce Island, Yenagoa, Bayelsa State, Nigeria

${ }^{*}$ Corresponding author: Burubai W, Department of Agricultural and Environmental Engineering, Faculty of Engineering, Niger Delta University, P.M.B. 071, Wilberforce Island, Yenagoa, Bayelsa State, Nigeria, Tel: (800)555-1212 ; E-mail: ebiburu@yahoo.com

Rec date: Feb 24, 2014; Acc date: Jul 07, 2014; Pub date: Jul 24, 2014

Copyright: ( 2014 Burubai W, et al. This is an open-access article distributed under the terms of the Creative Commons Attribution License, which permits unrestricted use, distribution, and reproduction in any medium, provided the original author and source are credited.

\begin{abstract}
In this study, some physical properties desirable to the design and development of handling and processing equipment, as well as the proximate composition of Ipoli fruit was evaluated. Results show that average values of length, width, thickness andgeometric mean diameter were $20.20 \mathrm{~mm}, 13.91 \mathrm{~mm}, 6.92 \mathrm{~mm}$ and $12.45 \mathrm{~mm}$ respectively at a moisture level of $85.2 \%$ (wet basis). Sphericity, aspect ratio, surface area and volume were found to be $62 \%, 70 \%, 438.27 \mathrm{~mm}^{2}$ and $1227.84 \mathrm{~mm}^{3}$ respectively, while coefficient of static friction on mild steel, rubber and plywood surfaces were found to be $1.294,1.140$ and 1.016 respectively. The nutritional facts also reveal that Ipoli fruit contains $6.2 \%$ Carbohydrate, $0.8 \%$ protein, $1.7 \%$ ash content, $0.18 \%$ Vitamin A and $0.42 \%$ Vitamin C. It is therefore recommended that Ipoli fruit consumption and cultivation be encouraged and the mechanization of its unit operations be considered.
\end{abstract}

Keywords: Physical Properties; Proximate Composition; Design

\section{Introduction}

Ipoli is to rain forest tree that is found in abundance in the Niger Delta region (Southern part) of Nigeria in Africa. It thrives well in the swampy areas andgrows to a height of about $20-25 \mathrm{~m}$. The leaves are elongated,glossy and leathery and about $8-18 \mathrm{~cm}$ in length and $3-6 \mathrm{~cm}$ broad. It has a stout stalk and petals of the flowers are whitish in colour and sepals persistent at the base of the fruit. The fruit has a single seed embedded in a creamy pulp which is the desired juice when harvested. Fruiting season of this highly tasty plant is normally between November to January annually, and the matured fruit is yellowish in colour (Figure 1). Ipoli fruit is, indeed, a delight not only to humans but an attractant to a variety of animals and birds, including Monkeys, Squirrels etc. Notwithstanding, Ipoli fruit is still considered a wild crop, but can be domesticated or cultivated for mechanized juice production activities. However, this can only be possible when proper scientific studies are conducted on its physical properties and proximate composition.

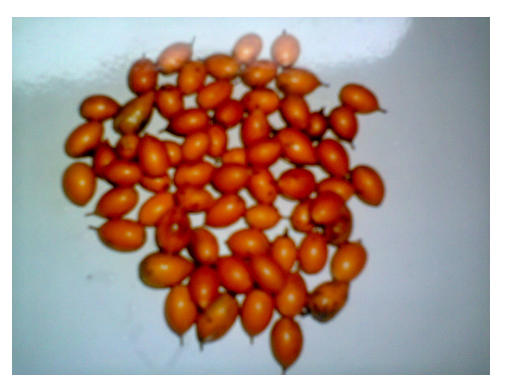

Figure 1: Sample of Ipoli Fruits
A study of the proximate composition of food is important as it reveals the nutritional facts for safety reasons. Thus, similar investigations have been done on various biomaterials to ascertain their fitness for human consumption [1-3]. Beyond the food value, mechanizing the various unit operations (presently manual) involved in the harvesting, handling and processing of Ipoli fruit underscores the need for the study of its physical properties. These properties includes mass, size, shape, surface area, volume, true density, bulk density, aspect ratio, sphericity, porosity etc. Size and shape of agricultural materials are important because they are used in screening solids to separate foreign materials andgrading of fruits and vegetable. Size and shape are also necessary in heat and mass transfer calculations and containerization of biomaterials. Aspect ratio and radius of curvature are needed to determine how easily an object will roll. Roundness and angle of repose are important for the design of conveyors for particulate foods. Bulk density, true density and porosity may be useful in designing hoppers and storage facilities. Pressure loads on storage structures also depends on bulk density, angle of repose and frictional coefficients on bin wall materials. It is against this backdrop, that several scientists have investigated the physical and mechanical properties of diverse agricultural and food products in order to provide a baseline data for process machine design. These includes Burubai et al. [4] for Africa nutmeg; for maize; Heidarbeigi et al. [5] for wild Pistachio; Kilickan et al. [6] for Spinach seed; Zewdu and Solomon [7] for tef seed; Ozarlan [8] for cotton seeds; gursoy andguzel, et al. [9] for wheatgrains; Aydin, et al. [10] for hazel nuts and Carman, et al. [11] for Lentil seeds. However, there is dearth of information on the physical properties of Ipoli fruit. Therefore, the objective of this study is to determine some physical properties and proximate composition of Ipoli fruit to aid design of processing and handling machines.

\section{Materials and Methods}

$10 \mathrm{~kg}$ of fresh Ipoli fruits were harvested from the Sabagreia forest on 20th of January, 2013. The fruits were taken to the Food Process 
Engineering Laboratory of the Niger Delta University and processed manually to remove all foreign materials. The initial moisture content was taken using the oven method and the remaining samples stored in a jute bag at a room temperature of $22^{\circ} \mathrm{C}$ for 24 hours before experimentation.

Samples of 100 fruits were taken and theirgeometric dimensions of length (major diameter), width (intermediate diameter) and thickness (minor diameter) measured using a digital vernier caliper (Models CD-6BS-Mitutoyo Corporation, Japan) with a resolution of $\pm 0.01 \mathrm{~mm}$. Thisgave rise to 100 replications in the measurements.

\section{Geometric Mean Diameter (GMD)}

Thegeometric mean diameter for the 100 fruits was determined using the measuredgeometric dimensions of length (L), width (W) and thickness $(\mathrm{T})$ in the following equation.

$$
G M D=(L W T)^{1 / 3}
$$

\section{Sphericity}

The shape of a food material is usually expressed in terms of its sphericity. It is an important property used in fluid flow and heat and mass transfer calculations. Sphericity was determined using the measuredgeometric dimensions in the formula.

$$
S=\frac{(L W T)^{1 / 3}}{L}
$$

However, for a detailed study of the shape of Ipoli fruit, aspect ratio was also calculated as follows [12]

$$
\text { Aspect ratio, } R=\frac{W}{L} \times 100
$$

\section{Kernel Weight (TKW)}

The mass of 100 fruits were weighed on a top loading electronic balance (EK 5350) with a resolution of $0.01 \mathrm{~g}$ and the resultant weight multiplied by 10 toget the 1000 kernel weight. This was also applied by Tavakoli et al. [13] for barleygrains andgharibzahedi et al. [14] for pine nut.

\section{Surface area and volume}

The surface area and volume of Ipoli fruit were calculated based on thegeometric mean diameter (GMD) in the following equations [15]

$$
\begin{aligned}
& S=\pi(G M D)^{2} \\
& V=\frac{\pi}{6}(G M D)^{3}
\end{aligned}
$$

\section{Radius of curvature}

This is an important property needed for the design of conveyors and chutes. It determines the rollability of objects. The minimum radius of curvature $\left(\mathrm{R}_{\min }\right)$ and maximum radius of curvature $\left(\mathrm{R}_{\max }\right)$ were calculated using the followings

$$
R_{\min }=\frac{H}{2}
$$

$$
R_{\max }=\frac{H^{2}+\frac{L^{2}}{4}}{2}
$$

Where, $\mathrm{H}$ is the average of thickness and length ( $\mathrm{mm})$.

\section{Angle of repose}

Angle of repose is an important physical property for the design of processing, storage, and conveying systems of particulate materials. When the materials are smooth and rounded, the angle of repose is low. For sticky and fine materials the angle of repose is high [4]. Angle of repose therefore indicates the cohesion amongst the individual units of the materials. It was determined using a bottomless cylinder $(10 \mathrm{~cm}$ diameter, $15 \mathrm{~cm}$ height) which was also applied by Taser et al. andgarvnayak et al. $[16,17]$. The cylinder was placed over a smooth surface and Ipoli fruits were filled in. the cylinder was raise slowly permitting the sample to flow down and form a natural slope. The height $(\mathrm{H})$ and diameter $(\mathrm{D})$ of the heap were measured and the dynamic angle of repose calculated as follows.

$$
\theta=\tan ^{-1} \frac{2 H}{D}
$$

\section{Bulk density}

Bulk density which is defined as the ratio of the mass of the sample to its container volume was evaluated by weighing an Ipoli-filled beaker of known weight and volume and calculated as follows [18].

$\rho_{b}=\frac{\text { Mass }}{\text { Volume }}=\frac{m}{V}$

Where $\rho b(\mathrm{~g} / \mathrm{cm} 3)$ is bulk density, mass $\mathrm{m}(\mathrm{g})$ of sample.

\section{True density}

This is the ratio of mass of sample to its pure volume. For Ipoli fruit, true density was determined by the water displacement method $[5,19]$. The true density was then calculated as

$$
\rho_{T}=\frac{\text { Mass of individual fruit }(\mathrm{kg})}{\text { Volume of individual seed }\left(\mathrm{m}^{3}\right)}
$$

\section{Porosity}

Porosity is a vital physical property that characterizes the amount of air spaces in a bulk. It is needed in modeling and design of various heat and mass transfer processes. It is defined as the volume fraction of air in the bulk sample and is calculated as

$$
\text { Porosity, } P=\frac{\rho T-\rho b}{\rho T} \times 100
$$

\section{Coefficient of static friction}

This is the ratio of force needed to start sliding the sample over a surface by the weight of the sample. The coefficient of static friction of Ipoli fruits was determined against three structural surfaces commonly used for post Harvest handling of biomaterials, namely; mild steel, rubber and plywood. This was done on a tilting-table apparatus. A wooden frame of $10 \mathrm{~cm} \times 10 \mathrm{~cm} \times 5 \mathrm{~cm}$ was filled with the fruits and lifted slightly about $2 \mathrm{~mm}$ to prevent contact with the test surface. The surface wasgradually raised with a screw device until the sample and the wooden frame just begin to slide down. The angle of inclination 
Citation: Burubai W, Amber B (2014) Some Physical Properties and Proximate Composition of Ipoli Fruits. J Food Process Technol 5: 343. doi:

Page 3 of 5

was measured with a protractor and the coefficient of static friction calculated as follows

coefficient of static friction, $\mu_{s}=\tan \alpha$

Where $\alpha$ is the angle of tilt of table.

\section{Proximate analysis}

The food value (chemical properties) of Ipoli fruits were evaluated at the Chemistry Laboratory of the Niger Delta University, Bayelsa State, Nigeria. They include moisture content, ash content, fat content, crude protein, carbohydrate, vitamin A and vitamin $\mathrm{C}$ content and were determined according to standard methods. Moisture content
(\%) was determined using the oven method, crude protein by the Kjeidahl apparatus method, carbohydrate by difference, ash content by method described by Pomeranz and Meloan [20], fat content by Soxhlet apparatus as described by Keraj and Muller [21]. The vitamins were also determined using standard procedures [1]. All determination were done in triplicate and statistically analysed.

\section{Results and Discussions}

A summary of the determined physical properties and proximate compositions of Ipoli fruits are presented in Tables 1 and 2 respectively.

\begin{tabular}{|c|c|c|c|c|c|c|c|}
\hline Physical Properties & Unit & Sample Size & Mean value & Minimum value & Maximum value & Standard deviation & $\begin{array}{l}\text { Coefficient } \\
\text { variability }\end{array}$ \\
\hline Moisture content & $\%$ & 5 & 85.2 & 84.71 & 86.31 & 2.04 & 0.024 \\
\hline Length & $\mathrm{mm}$ & 100 & 20.02 & 17.5 & 22.26 & 1.28 & 0.064 \\
\hline Width & $\mathrm{mm}$ & 100 & 13.91 & 11.25 & 16.13 & 1.13 & 0.081 \\
\hline Thickness & $\mathrm{mm}$ & 100 & 6.92 & 5.63 & 8.07 & 0.52 & 0.075 \\
\hline GMD & $\mathrm{mm}$ & 100 & 12.45 & 11.1 & 14.01 & 0.78 & 0.063 \\
\hline Sphericity & $\%$ & 100 & 0.62 & 0.57 & 0.72 & 0.04 & 0.065 \\
\hline Aspect Ratio & $\%$ & 100 & 0.7 & 0.61 & 0.86 & 0.06 & 0.086 \\
\hline Unit Mass & $\mathrm{g}$ & 100 & 1.82 & 1 & 3 & 0.52 & 0.286 \\
\hline TKW & g & 5 & 1820 & 1819 & 1832 & 2.35 & 0.001 \\
\hline Surface Area & $\mathrm{mm}^{2}$ & 100 & 438.27 & 387.08 & 616.63 & 8.29 & 0.019 \\
\hline Volume & $\mathrm{mm}^{3}$ & & 1227.84 & 716.09 & 1439.84 & 15.31 & 0.013 \\
\hline Rmin & $\mathrm{mm}$ & 100 & 6.95 & 6.13 & 8.07 & 0.57 & 0.082 \\
\hline Rmax & $\mathrm{mm}$ & 100 & 10.58 & 9.31 & 11.61 & 0.6 & 0.057 \\
\hline Angle of repose, $\theta$ & 0 & 3 & 22.5 & 21.8 & 23.4 & 1.03 & 0.046 \\
\hline Bulk Density & $\mathrm{kg} / \mathrm{m}^{3}$ & 10 & 531.04 & 523.26 & 568.41 & 10.46 & 0.02 \\
\hline True Density & $\mathrm{kg} / \mathrm{m}^{3}$ & 10 & 1482.28 & 1293.82 & 1631.05 & 22.54 & 0.015 \\
\hline Porosity & $\%$ & 10 & 63.25 & 49.87 & 68.53 & 4.26 & 0.067 \\
\hline Mild steel & Rad & 3 & 1.294 & 1.189 & 1.386 & 0.125 & 0.097 \\
\hline Rubber & Rad & 3 & 1.14 & 0.897 & 1.274 & 0.101 & 0.089 \\
\hline Plywood & Rad & 3 & 1.061 & 0.801 & 1.173 & 0.11 & 0.108 \\
\hline
\end{tabular}

Table 1: Some Physical Properties of Ipoli Fruits

The moisture content of fresh Ipoli fruit was found to be $85.20 \%$ (wet basis). This value is higher than those of African nutmeg [4], Parkia Specioca [19] and Spinach. Therefore, the high moisture content is an indication that Ipoli fruit has a short storage life; hence proper preservation methods must be applied to maintain its freshness during storage.

\section{Dimensional properties}

At the above moisture level, mean values of length, width and thickness are shown in Table 1. Results indicate that Ipoli fruit has mean values of length, width and thickness of $20.02 \pm 1.28 \mathrm{~mm}, 13.91$ $\pm 1.13 \mathrm{~mm}$ and $6.92 \pm 0.52 \mathrm{~mm}$ respectively. These values are higher than those of Jetropa seeds [17], wild pistachio [5] and African nutmeg [4]. 
These dimensional properties are essential for the design of sieve apertures for cleaning and sorting operations as well as the development of chutes and hoppers. More so, since the three semiaxes of the fruit are not equal, the shape of Ipoli fruit can be considered as a scalene ellipsoid. Alsogeometric mean diameter which is a function of the length, width and thickness was found to vary between $14.01 \mathrm{~mm}$ and $11.10 \mathrm{~mm}$ with a mean value of $12.45 \mathrm{~mm}$. Thegeometric mean diameter value obtained here is higher than that of Sesame seeds [22].

The sphericity of Ipoli fruit varied between $72 \%$ and $57 \%$ with a mean value of $62 \%$. Similarly, aspect ratio which is another shape factor varied between $86 \%$ and $61 \%$ with a mean value of $70 \%$ as shown in Table 1 . This shows that Ipoli fruit has a higher sphericity than wild pistachio seed [5] but is similar to those of Sesame seeds [22] and Parkia speciosa seeds. These low sphericity and aspect ratio values reveals that Ipoli fruit is most likely to slide than roll on flat surfaces and these values are needed for hopper and chute designs.

\begin{tabular}{|l|l|l|}
\hline Characteristics & $\begin{array}{l}\text { Obtained values } \\
\mathbf{\pm S . D} \text { ) }\end{array}$ & $\begin{array}{l}\text { Coefficient } \\
\text { variability }\end{array}$ \\
\hline Moisture content (\%) & $85.20 \pm 2.04$ & 0.024 \\
\hline Ash content (\%) & $1.70 \pm 0.14$ & 0.082 \\
\hline Fat (\%) & $0.50 \pm 0.42$ & 0.84 \\
\hline Crude protein (\%) & $0.80 \pm 0.25$ & 0.31 \\
\hline Total carbohydrate (\%) & $6.20 \pm 0.11$ & 0.018 \\
\hline Vitamin A (\%) & $0.18 \pm 0.06$ & 0.33 \\
\hline Vitamin C (\%) & $0.42 \pm 0.13$ & 0.31 \\
\hline
\end{tabular}

Table 2: Proximate Composition of ipoli Fruit

At the $85.20 \%$ moisture content, the average unit mass of Ipoli fruit was observed to change between $3.0 \mathrm{~g}$ and $1.0 \mathrm{~g}$ with a mean value of $1.82 \mathrm{~g}$ which is close to the mean mass of Parkia Speciosa. Table 1 also shows that Ipoli fruit had mean surface area and volume values of $438.27 \mathrm{~mm}^{2}$ and $1227.84 \mathrm{~mm}^{3}$ respectively. These values are needed for containerization and packaging design. The minimum radius of curvature was noted to vary between $8.07 \mathrm{~mm}$ and $6.13 \mathrm{~mm}$ with an average value of 6.92 . Also an average of $10.58 \mathrm{~mm}$ was recorded for maximum radius of curvature. These figures are required not only for hopper and conveyor designs but for the calculation of elastic modulus of Ipoli fruit using Herzt theory. Furthermore, true density and bulk densities of the fruits were found to be $1482.28 \pm 22.54 \mathrm{~kg} / \mathrm{m}^{3}$ and $531.04 \pm 10.46 \mathrm{~kg} / \mathrm{m}^{3}$ respectively. Literature reveals that true density of Parkia speciosa and quinoa seeds [23] are similar to that of Ipoli fruit. The density data shows that Ipoli fruit is heavier than both air and water. These properties are therefore useful in designing separation processes.

Coefficient of static friction which is required in designing chutes, hoppers, bins and conveyors was determined against mild steel, rubber and plywood surfaces. Results (Table 1) show that average coefficient of static friction values of $1.294,1.140$ and 1.016 were recorded against mild steel, rubber and plywood surfaces respectively. These values aregreater than the values reported for cucurbit seeds and wild pistachio. This may be attributed to the high moisture content in the seeds and the guminess of the surface of the fruit. However, mild steel had the highest coefficient of static friction and the lowest value was observed in plywood.

Results (Table 2) show that Ipoli fruit contains some food value as it is composed of $1.70 \%$ ash content, $0.50 \%$ fat, $0.80 \%$ crude protein, $6.20 \%$ carbohydrate, $0.18 \%$ vitamin A and $0.42 \%$ vitamin C. Although crude protein and ash content of Jatropha seed [21] are higher, Ipoli fruit contains more vitamins (A and C) which is deficient in Jatropha seed. Data therefore indicates that Ipoli fruit contains more of Carbohydrate, protein and vitamins, hence its consumption should be encourages and its domestication a policy [24].

\section{Conclusion}

An investigation of some physical properties and proximate composition of Ipoli fruit was conducted and results show that:

(a) The fresh fruit contains about $85.20 \%(\mathrm{wb})$ moisture content

(b) The length, width, thickness, andgeometric mean diameters of the fresh fruits are $20.02 \mathrm{~mm}, 13.91 \mathrm{~mm}, 6.92 \mathrm{~mm}$ and $12.45 \mathrm{~mm}$ respectively. Also the average values of sphericity, aspect ratio and unit mass were $62 \%, 70 \%$ and $1.82 \mathrm{~g}$ respectively.

(c) Average values of angle of repose, bulk density, true density and porosity were found to be $22.5 ; 531.04 \mathrm{kgm}^{-3}, 1482.28 \mathrm{kgm}^{-3}$ and $63.23 \%$ respectively.

(d) Coefficient of static friction values were noted to be 1.294, 1.140 and 1.018 for mild steel, rubber and plywood surfaces respectively.

(e) The food value of Ipoli fruit is about $0.8 \%$ protein, $0.5 \%$ fat, $6.2 \%$ carbohydrate, $1.7 \%$ ash, $0.18 \%$ vitamin A and $0.42 \%$ vitamin C.

Therefore, information provided in this study may be relevant to engineers and food processors for decision making

\section{Acknowledgement}

The authors are verygrateful to the staff of both the Chemistry Laboratory and the Food Process Engineering Laboratory of the Niger Delta University for their assistance while the experiments lasted.

\section{References}

1. Asibey BE, Tayie FK (1999) Proximate Analysis of Some Underutilizedghanian Vegetables.ghana J Sci 39: 91-92.

2. Calisir SM, Ugur M, Yildiz A (2005) A study on some physic-chemical properties of Turkey Okra seeds. J of Food Engineering 68: 73-78.

3. Savello PA, Martin F, Hill JM (1982) Nutritional Composition of Okra seed meal. J Agric Food Chem 28: 1163- 1166.

4. Burubai W, Akor AJ, Igoni HA, Puyate YT (2007) Some physical properties of African nutmeg. International Agrophysics 21: 123-126.

5. Heidarbeigi K, Ahmadi H, Tabatabaeefar A (2008) Some physical and mechanical properties of Iranian wild Pistachio. American-Eurasian J Agric \& Environ Sci 3: 521-525.

6. Kilickan A, Ucer N, Yalcin I (2010) Some physical properties of Spinach seed. African Journal of Biotechnology 9: 648-655.

7. Zewdu AD, Solomon WK (2007) Moisture-dependent Physical properties of tef seed. Biosyst Eng 96: 57-63.

8. Ozarlan C (2002) Physical properties of Cotton seed. Biosyst Eng 83: 169-174.

9. Gursoy S,guzel E (2010) Determination of Physical Properties of Some Agriculturalgrains. Research Journal of Applied Sciences, Engineering and Technology 2: 492-498. 
Citation: Burubai W, Amber B (2014) Some Physical Properties and Proximate Composition of Ipoli Fruits. J Food Process Technol 5: 343. doi:

10. Aydin C (2002) Physical Properties of hazel nuts. Biosystems Engineering 82: 297-303.

11. Carman K (1996) Some physical properties of Lentil seeds. J Agric Eng Res 63: 87-92.

12. Maduako JN, Faborode MO (1990) Some Physical Properties of Cocoa pods in relation to primary processing. Ife J Technol 2: 1-7.

13. Tavakoli M, Tavakoli H, Ahmadi H (2009) Moisture- dependent physical properties of barleygrains. International Journal of Agricultural and Biological Engineering 2: 341-350.

14. Gharibzahedi S, Etemad V, Foshat M (2010) Moisture dependent engineering properties of black cumin seed. Agric Eng. Int: CIGR.

15. Jonathan A, Ato B, Dzisi KA (2012) Effect of rewetting on selected physical properties of 'Asontein' Cowpea variety. ARPN Journal of Engineering and Applied Sciences 7: 389-395.

16. Taser OF, Altuntas E, Ozgoz E (2005) Physical Properties of Hungarian and Common vetch Seeds. J Appl Sci 5: 323-326.

17. Garvnayak DK, Pradhan R, Nalk SN (2008) Moisture dependent physical properties of Jatropha seed. Industrial crops Products 27: 127-129.
18. Baryeh EA (2000) Physical properties of bambaragroundnuts. Journal of Food Engineering 47: 321-326.

19. Abdullah MR, Chng PE, Lim TH (2011) Some Physical Properties of Parkia Speciosa Seeds. International Conference on Food Engineering and Biotechnology, IPCBEE, IACSIT Press, Singapore.

20. Pomeranz Y, Meloan C (1994) Food Analysis; Theory and practice. (3rd Edtn). Chapman and Hall, New York.

21. Milani E, Seyed M, Vahedi N, Nikzadeh V (2007) Moisture- dependent physical properties of Cucurbit seeds. Int. Agrophysics 21: 157-168.

22. ArafagK (2007) Some physical and mechanical properties of Sesame Seeds Concerning the Selection of Seperation Unit. Misr J Ag Eng 24: 415-429.

23. Vilche C,gely M, Santalla E (2003) Physical Properties of quinoa seeds. Biosyst Eng 86: 59-65.

24. Bent PA, Addo A, Dzisi KA (2005) Effect of rewetting and drying on selected physical properties of "Obatanpa" maize variety. Journal of theghana Institute of Engineers 3: 89-96. 